\title{
Cattle Feeding and Resting Patterns in a Foothills Riparian
}

Zone

\section{CLAYTON B. MARLOW AND THOMAS M. POGACNIK}

\begin{abstract}
Cattle impact on riparian areas is dependent upon both their behavior and utilization of streamside vegetation. Development of grazing strategies for riparian environments would be enhanced by an understanding of cattle behavior in riparian and adjacent uplands. Results of a 2-year behavior study indicate that a seasonal trend in cattle use of riparian and upland areas exists. Unless low precipitation limited upland forage quality/production, cattle spent a significant $(P<0.05)$ amount of their feeding time in upland areas during late June and early July. Significant levels of feeding activity $(P<0.05)$ occurred in the riparian zone from late August through September. Resting patterns differed only during the early part of the grazing season when cattle spent significantly more $(P<0.05)$ of their time resting in upland areas. During late July, August, and September, there was no significant difference $(P>0.50)$ in the amount of time spent resting in either zone. Significant differences $(P<0.05)$ occurred only when adverse weather conditions caused cattle to seek shelter in the riparian zone. Because cattle spend a disproportionate amount of their feeding time in the riparian zone during late summer and early fall, impacts could be limited by basing stocking rates for this period only on forage available in the riparian zone.
\end{abstract}

Although cattle impact to riparian areas is dependent upon both behavior and utilization of streamside vegetation (Platts 1982, WADFS 1980), only a limited number of studies (Roath and Krueger

Authors are assistant professor, Animal and Range Sciences Department, Montana State University, Bozeman 59717 and range conservationist, USDI, Bureau of Land Management, Tonopah, Nev. 89049.

Research was funded by Water Resources Division, Montana Department of Natural Resources and Conservation Grant No. WDG-84-5005. Authors wish to thank Mr. Brad P. Lough and Ms. Debra Murphy for assistance in collection and summarization of field data.

Manuscript accepted 29 August 1985 1982a, Bryant 1982) have directly addressed cattle behavior in this environment. Development of effective grazing management for riparian zones depends upon how livestock are controlled (Davis 1982). For example, Roath and Krueger (1982a) reported that increased cattle presence in riparian areas during the early part of the grazing season was due in large part to where cattle were released in the pasture. Several reports (Bryant 1982, Myers 1981, Severson and Boldt 1978) suggest that cattle tend to congregate more frequently in riparian zones during "hot" summer months. This has given rise to the concept of spring or fall and winter grazing to mitigate cattle damage in riparian areas. But, repeated spring grazing may lead to reduced condition of upland vegetation communities, which in turn could lead to increased sediment loads in nearby streams (Branson et al. 1972). Consequently, it may be necessary for cattle to graze pastures containing riparian zones during the critical summer months every $2-4$ years depending upon the type of grazing system used. A minimum of 2 years was necessary for willow (Salix spp.) to recover from heavy utilization (Smith, B.H. unpublished report. Riparian Willow Management USDI-BLM, Rock Springs, Wyo.) while Marcuson (1977) suggested that it may take 25 years of total protection from grazing and destructive floods for a severely disturbed riparian system to recover. The question is, will rest from grazing once every $2-4$ years be sufficient for recovery or are different grazing strategies necessary to rehabilitate deteriorated riparian communities?

More information on how and when cattle utilize riparian areas may enable resource managers to better control animal impact and enhance riparian recovery. In an attempt to develop grazing strategies specifically for maintenance and improvement of riparian zones, a long-term riparian grazing study was initiated on the Montana Agricultural Experiment Station's Red Bluff Research 


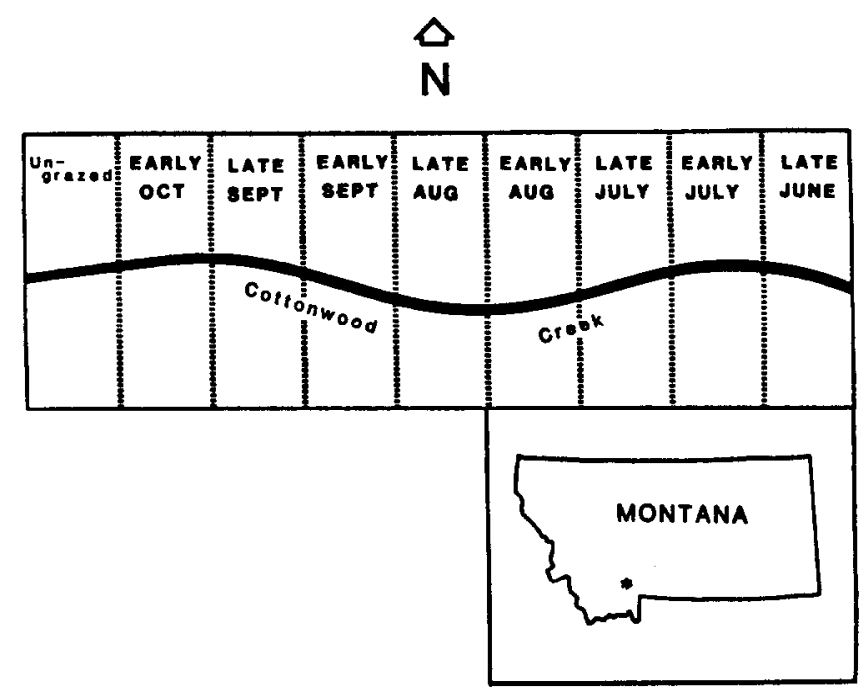

Fig. 1. Pasture design and approximate grazing dates. Inset shows location of study site, Red Bluff Research Ranch, Montana.

Ranch (Fig. 1). This paper reports one phase of this study, which was to describe feeding and resting behavior of cattle utilizing a foothills riparian zone.

\section{Study Site Description}

The Cottonwood Creek watershed (1,360 ha) was selected as the study site in 1981 . Topography is characterized by moderate to steep slopes with elevations ranging from $2,000 \mathrm{~m}$ at the headwater spring to $1,400 \mathrm{~m}$ where it enters the Madison River. The stream is bordered on the south by slopes of $30-50 \%$ and on the north by rolling hills with $15-30 \%$ slopes.

For purposes of this study, vegetation types and landforms are collectively referred to as either upland or riparian zones. The riparian community is composed of aspen, aspen/willow, bog, meadow, and streambank vegetation types while the upland community is composed of upland/grassland, sagebrush, and aspen park vegetation types.

The riparian community is dominated by Kentucky bluegrass (Poa pratensis L.), redtop (Agrostis stolonifera L.), timothy (Phleum pratense L.), smooth brome (Bromus inermis Leyss.), beaked sedge (Carex rostrata Stokes), Sprengel's sedge (Carex sprengelii Dewey), and white clover (Trifolium repens L.). Overstory includes quaking aspen (Populus tremuloides Michx.), willow (Salix spp. L.), chokecherry (Prunus virginiana L.), and swamp gooseberry (Ribes lacustre (Pers.) Poir.).

The upland community supports Kentucky bluegrass, green needlegrass (Stipa viridula Trin.), needleandthread (Stipa comata Trin. \& Rupr.), bluebunch wheatgrass (Agropyron spicatum (Pursh.) Scribn. \& Smith), western wheatgrass (Agropyron smithii Rydb.), Idaho fescue (Festuca idahoensis Elmer), and cheatgrass brome (Bromus tectorum L.). Scattered, dense stands of mountain big sagebrush (Artemisia tridentata subsp. vaseyana (Rydb.) Beetle) interspersed with Woods rose (Rosa woodsii Lind L.) and Rocky Mountain juniper (Juniperus scopulorum Sarg.) occur throughout.

Soils within the study area are either Typic Cryorthents or Typic Cryoborolls in the uplands and Argic Cryoborolls in the riparian zone. Loams and loamy sands are characteristic of the colluviumderived upland soils while sandy loams and loamy sands occur in the alluvial deposits along the stream.

Mean daily air temperatures range from $20^{\circ} \mathrm{C}$ in July and August to $-11^{\circ} \mathrm{C}$ in December. The 400 to $500 \mathrm{~mm}$ of total annual precipitation occurs mainly in the form of winter snowfall. Snowdrifts remain on northern exposures and in the stream bottom into
May. Approximately $40 \%$ of the annual total results from rainfall during May and June.

\section{Methods}

\section{General Study Design:}

The basic study design consisted of 80.6 -ha paddocks lying along Cottonwood Creek (Fig. 1). Paddocks were small to assure heavy cattle use of the riparian zone as reported by Roath and Krueger (1982b) and to include similar riparian communities in all 8 paddocks. Because of the high availability of riparian habitat (40-50\% of the total) cattle use of riparian and upland zones surrounding the study site was monitored during the same period as a check for paddock size bias. Results indicated: (a) there was no significant difference $(P>.05)$ in use of habitats for feeding, and (b) use of riparian areas differcd significantly $(P>.005)$ only in that the study cattle selected a different riparian vegetation type to rest in than did the control cattle outside the enclosure. Grazing began the second week of June and ended the first week of October. Four yearling heifers grazed each paddock for 2 weeks and then were moved to the next paddock upstream. Consequently, each paddock was grazed only once but at the same time each year.

\section{Behavior Observations:}

Cattle-use patterns were based on 2, 24-h observation periods each week in 1982 and 1983 for a total of 32 observation periods each year. The activity and zone (riparian or upland) occupied by each heifer was recorded hourly during the observation period. This produced 96 total observations per "day" and 384 for the entire grazing period (approximately $29 \%$ of the time the heifers were in each paddock). Although observation intervals of greater than $\mathbf{3 0}$ minutes are not recommended for behavior studies due to underestimation of time spent walking, drinking, or defecating (Hull et al. 1960, Nelson and Furr 1966), time constraints necessitated the use of 60-minute observation intervals in this study. Consequently, activity was recorded only as feeding or resting. This is supported by Nelson and Furr (1966), who noted that large deviations in activities recorded at 60 -minute intervals did not appear to be associated with mean time involved in that activity. Additional reduction in observation variation may have been achieved with: (a) long observation periods ( 24 consecutive hours), (b) more observation periods during the study period, and (c) more individuals under observation.

Cattle were weighed each time they were moved from one paddock to the next. This information was used in monitoring cattle response to forage conditions. To supplement the behavior data, air temperature and wind speed were recorded on an hourly basis. Differences in use patterns between upland and riparian zones during 1982 and 1983 were tested for significance with a pair $t$ test at the 0.05 level (Gomez and Gomez 1984).

\section{Results and Discussion}

Cattle use of riparian and upland areas exhibited a general seasonal pattern. This pattern was most obvious in 1982 (Fig. 2a) when upland use declined steadily from early July until early October, while riparian use increased. Although the pattern was less distinct in 1983 (Fig. 2b), cattle still appeared to use uplands most heavily in early July and riparian areas most in late August. Dissimilarity between the 2 years probably arose from: (a) missing data for late September, 1982, and (b) a major shift in use patterns during early October, 1983 (Fig. 3).

Concentrated feeding activity in either zone occurred only during early July, early September, and late September (Fig. 3). In early July of both years, cattle spent a significant amount of time feeding in the uplands. Riparian areas were not used at significantly higher levels until the last 6 weeks of the grazing season. The concentration of feeding activity in the riparian zone during September may be due to the presence of higher quality forage in these 
(a)

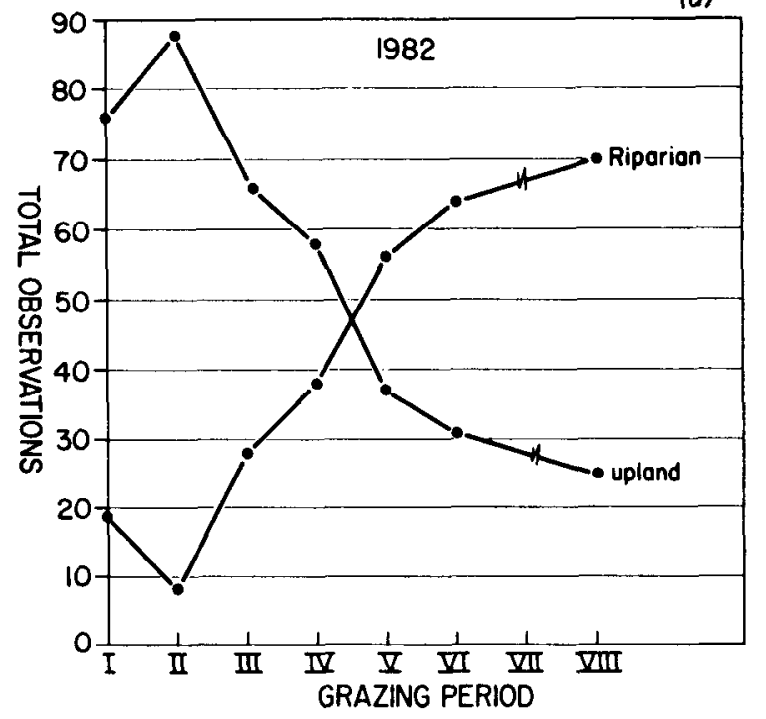

(b)

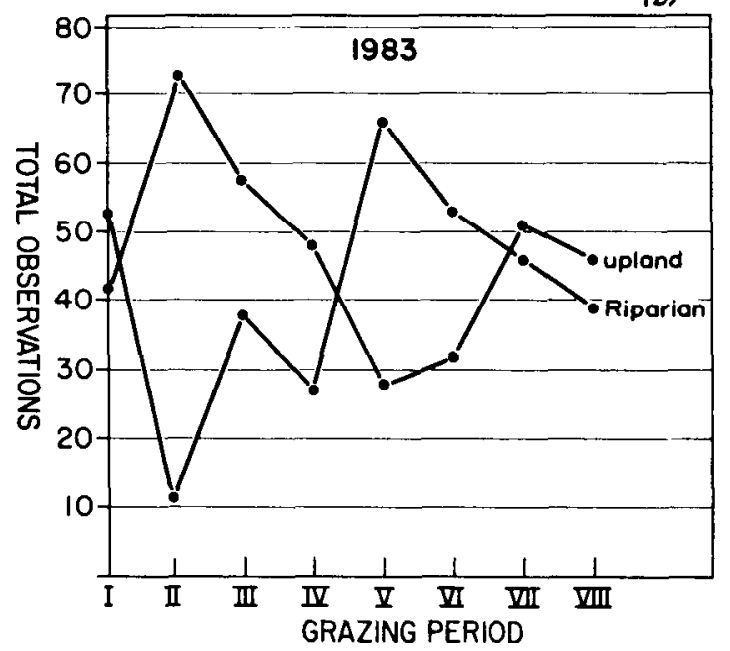

Fig. 2. Seasonal use of upland and riparian zones by cattle in 1982 and 1983. Roman numeral $I=$ late June, $I I=$ early July, $I I I=$ late July, $I V=$ early August, $V=$ late August, $V I=$ early September, $V I I=$ late September and $V I I I=$ early October.

well-watered areas. Kauffman et al. (1983) reported that during late August and September riparian forages were generally more palatable and higher in nutrient quality than those in the upland zone.

Cattle generally spent less time feeding in upland areas in 1983 than they had in 1982. This is apparent when feeding levels during late June and late July are compared (Fig. 3a and 3b). Riparian zones were probably used more in 1983 because pre-grazing precipitation was significantly lower than the amounts which occurred in the same period in 1982 (Fig. 4). Lack of rainfall during late June, 1983 (Fig. 4) probably further stressed upland forage quality and productivity and caused cattle to spend more time feeding in the riparian zone (Fig. 3b). Significantly greater use of uplands during early July, 1983 (Fig. 3b) may have resulted from there being less forage available in the riparian zone of the paddock being grazed. This paddock lacked the extensive Carex rostrata and $C$. sprengelii communities of the other paddocks. Consequently, cattle had to feed more in the uplands to meet daily intake requirements. Low upland forage productivity or quality in early July, 1983 was

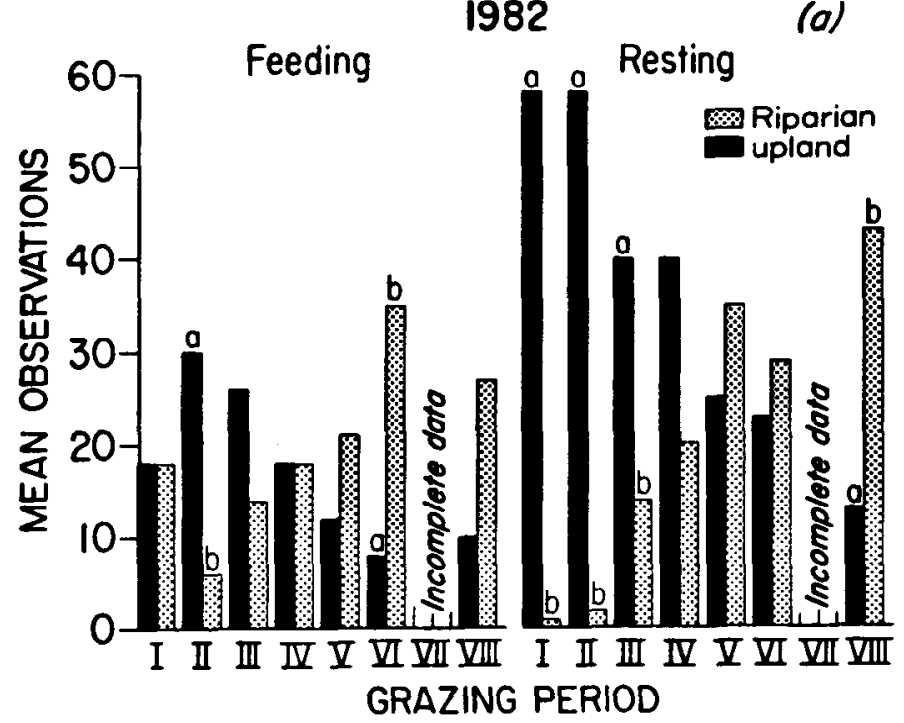

1983

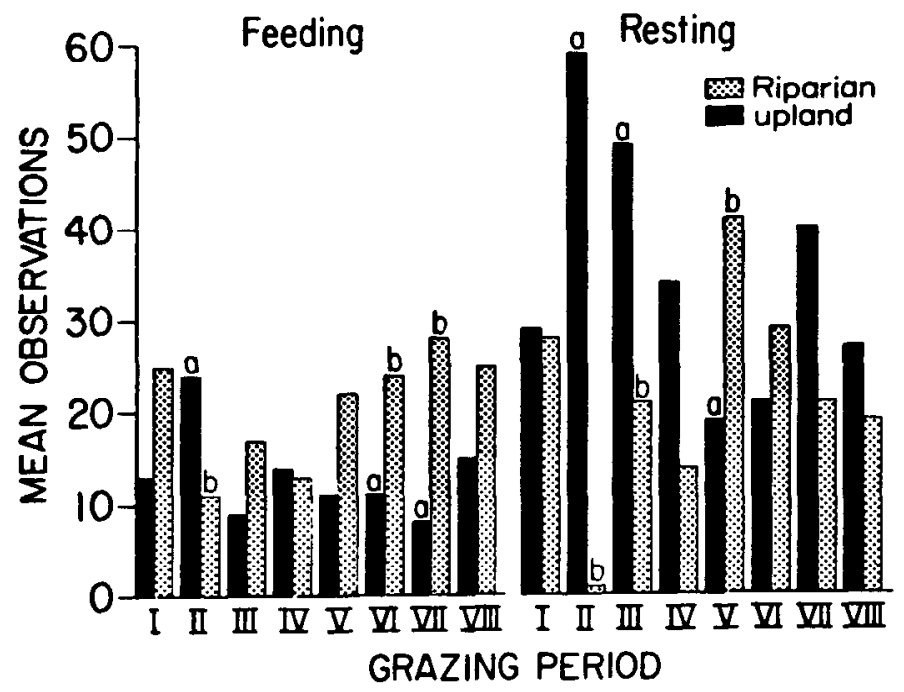

Fig. 3. Breakdown of cattle use patterns for each grazing period in 1982 and 1983. Bars with letters were significantly different at the 0.05 level. Roman numeral I = late June, $I I=$ early July, III = late July, $I V=$ early August, $V=$ late August, $V I=$ early September, $V I I=$ late September and VIII = early October.

apparent because cattle lost weight at a rate of $0.72 \mathrm{~kg}$ per day while they had gained $0.77 \mathrm{~kg}$ per day in the same paddock in 1982 .

The presence of significantly greater riparian feeding in early September of both years suggests that had observation data for late September, 1982, been available, preferential use of riparian areas would have continued through September. Lack of a significant difference in feeding patterns in early October, 1983, probably resulted from milder climatic conditions and increased precipitation (Fig. 4) which provided better upland forage conditions late in the grazing season.

Use of riparian and upland areas for resting is shown in Figure $3 a$ and $b$. In July cattle spent significantly more time resting in upland areas during both years. The lack of a significant difference between upland and riparian zones for resting during late June, 1983 , arose from higher riparian use: 28 counts/ $24 \mathrm{~h}$ in $1983 \mathrm{vs.} 1$ count $/ 24 \mathrm{~h}$ in 1982 . This is difficult to explain with climatological data because air temperatures in late June 1983 were significantly 


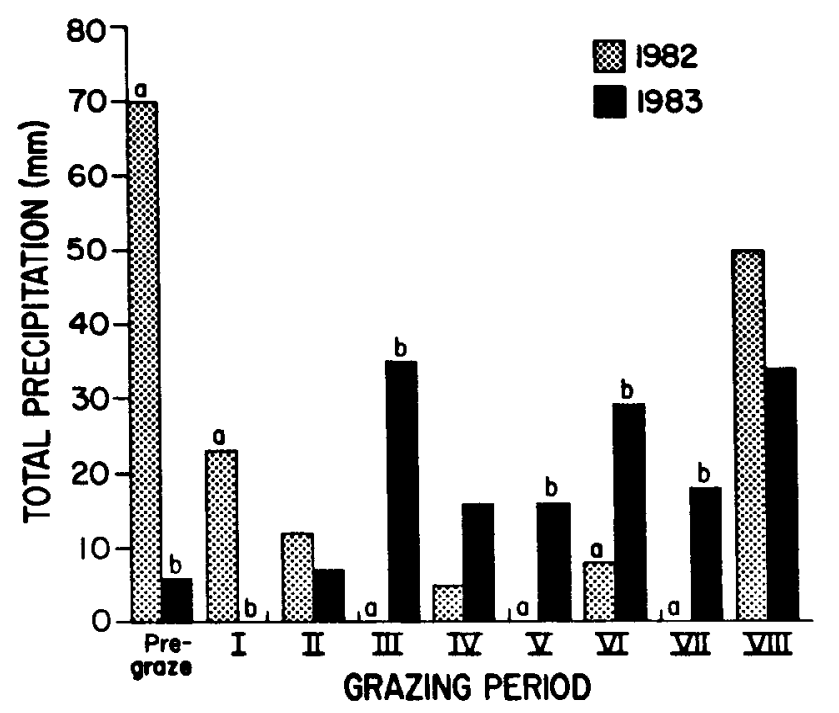

Fig. 4. Seasonal precipitation levels for 1982 and 1983. Bars with letters represent periods with significantly different $(\mathrm{P}<0.05)$ levels of precipitation. Roman numeral $I=$ late June, $I I=$ early July, $I I I=$ late July, $I V=$ early August, $V=$ late August, $V I=$ early September, $V I I=$ late September and $V I I I=$ early October.

lower than during the same time in 1982 (Fig. 5). If resting use was solely a function of temperature response, then use patterns should have also differed.

A possible explanation is the apparent increase in feeding in the riparian zone during late June, 1983. Because cattle appeared to rest in close proximity to where they last fed, the elevated use of riparian areas for feeding in late June (Fig. 3b) may have contributed to the higher level of resting.

Another difference between years was the increased level of resting in the riparian zone during late August, 1983 (Fig. 3b). Nighttime temperatures during this period were significantly lower than in 1982 (Fig. 5). Lower temperatures probably limited insect pest activity and allowed cattle to rest where they had been feeding. It is also important to note that feeding levels had increased in the riparian zone during the same period (Fig. 3b). Although the mean riparian resting count was higher than the upland count during early September of both years, day to day variation reduced differences between upland and riparian areas to a nonsignificant level. The lack of significant differences between upland and riparian zones continued through the remainder of the grazing season except early October 1982. The reason for this difference may be explained by reviewing resting patterns during daily activity intervals.

To determine cattle rest intervals, the 24-h observation period was divided into 4 activity periods. The first period was marked by the onset of grazing at about $0500 \mathrm{hr}$ (MST). Grazing generally ended at $0900 \mathrm{hr}$ when the cattle bedded down and began to ruminate. This resting period lasted until 1500 to $1600 \mathrm{hr}$, when cattle once more began to graze. At $2200 \mathrm{hr}$, the cattle usually bedded down and ruminated and rested until $0500 \mathrm{hr}$ the following morning. Squires (1981), Roath and Krueger (1982b), and Kilgour and Dalton (1984) reported the same activity pattern with one exception. Squires (1981) and Kilgour and Dalton (1984) report that a 1 to 2-hour feeding period occurred around $2400 \mathrm{hr}$. In this study, cattle were observed feeding at $2300 \mathrm{hr}, 0300 \mathrm{hr}$ and $0400 \mathrm{hr}$, but these events were infrequent and never amounted to more than $4 \%$ of the total observations. Although there was significantly more grazing activity during the periods from 0500 to $0900 \mathrm{~h}$ and 1600 to $2200 \mathrm{~h}$, cattle were observed to rest and feed at all hours throughout the observation period.

Examination of daily rest intervals indicated a seasonal trend similar to the trend for total use (Fig. 6). During 1982, cattle rested
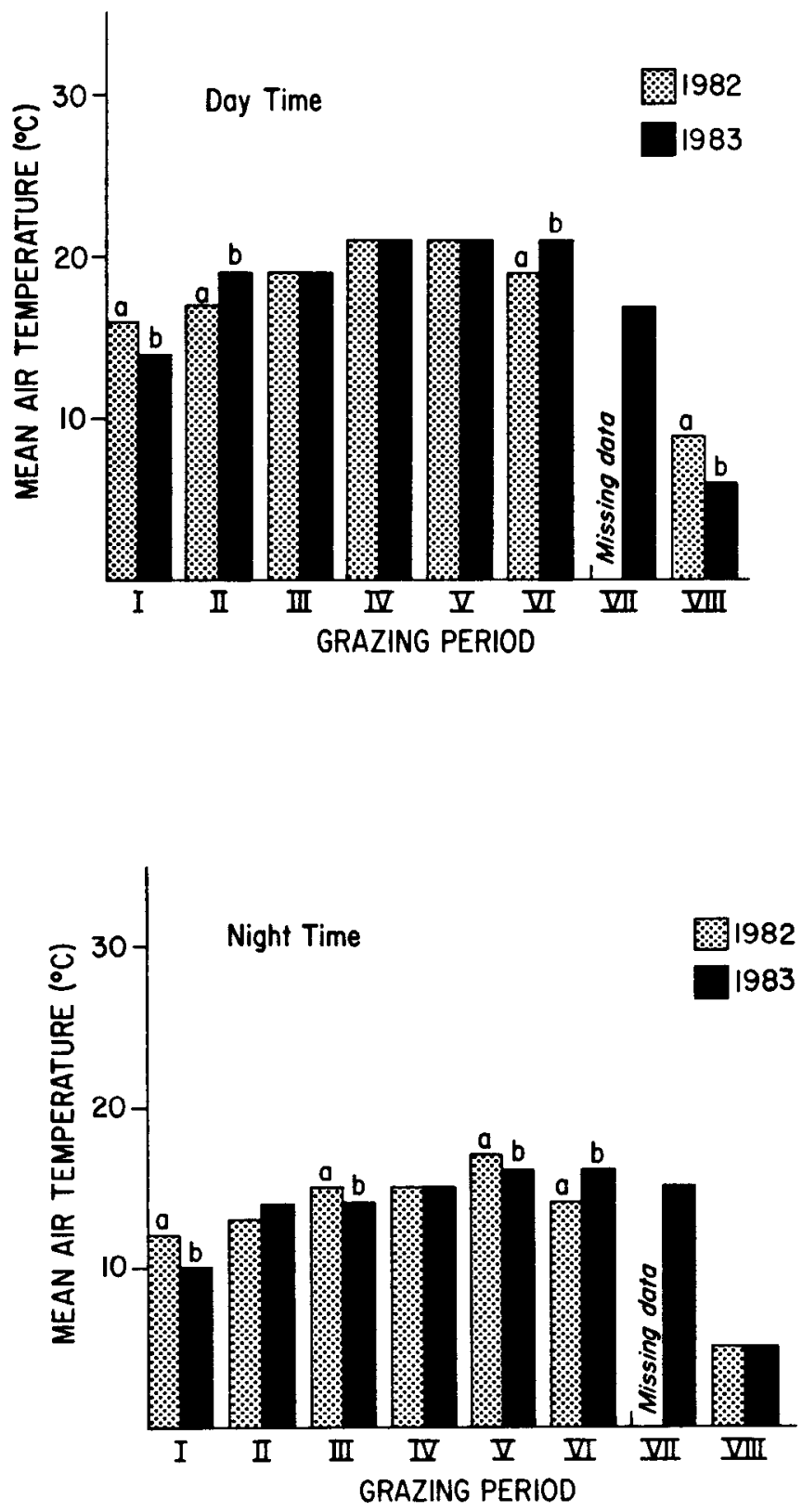

Fig. 5. Daytime and nighttime temperatures during each grazing period. Bars with letters are significantly different at the 0.05 level. Roman numeral $I=$ late June, $I I=$ early July, III = late July, $I V=$ early August, $V=$ late August, $V I=$ early September, $V I I=$ late September and $V I I I=$ early October.

more in the uplands during all hours of the day in the first half of the grazing season and more in the riparian zone during the last half. In late July and early August, $60 \%$ of the time cattle spent resting in the riparian zonc was done during darkness (Fig. 6a). However, by late August, nighttime use had dropped to $51 \%$ and dropped again in early September to $34 \%$ of the total observations. But, resting in the riparian zone during darkness increased to $69 \%$ of the total observations in early October, 1982. During this time there were 2 consecutive observation periods where wind speeds were 2-3 $\mathrm{ms}^{-1}(4-7 \mathrm{mph})$ and temperatures were $0.5^{\circ} \mathrm{C}$ to $5^{\circ} \mathrm{C}$. This probably caused cattle to seek shelter from wind and low air temperatures in the riparian zone.

Hourly resting patterns in 1983 (Fig. 6b) showed more resting in the uplands during late June and early July and nearly equal use of both zones thereafter. The most notable exception was during early 

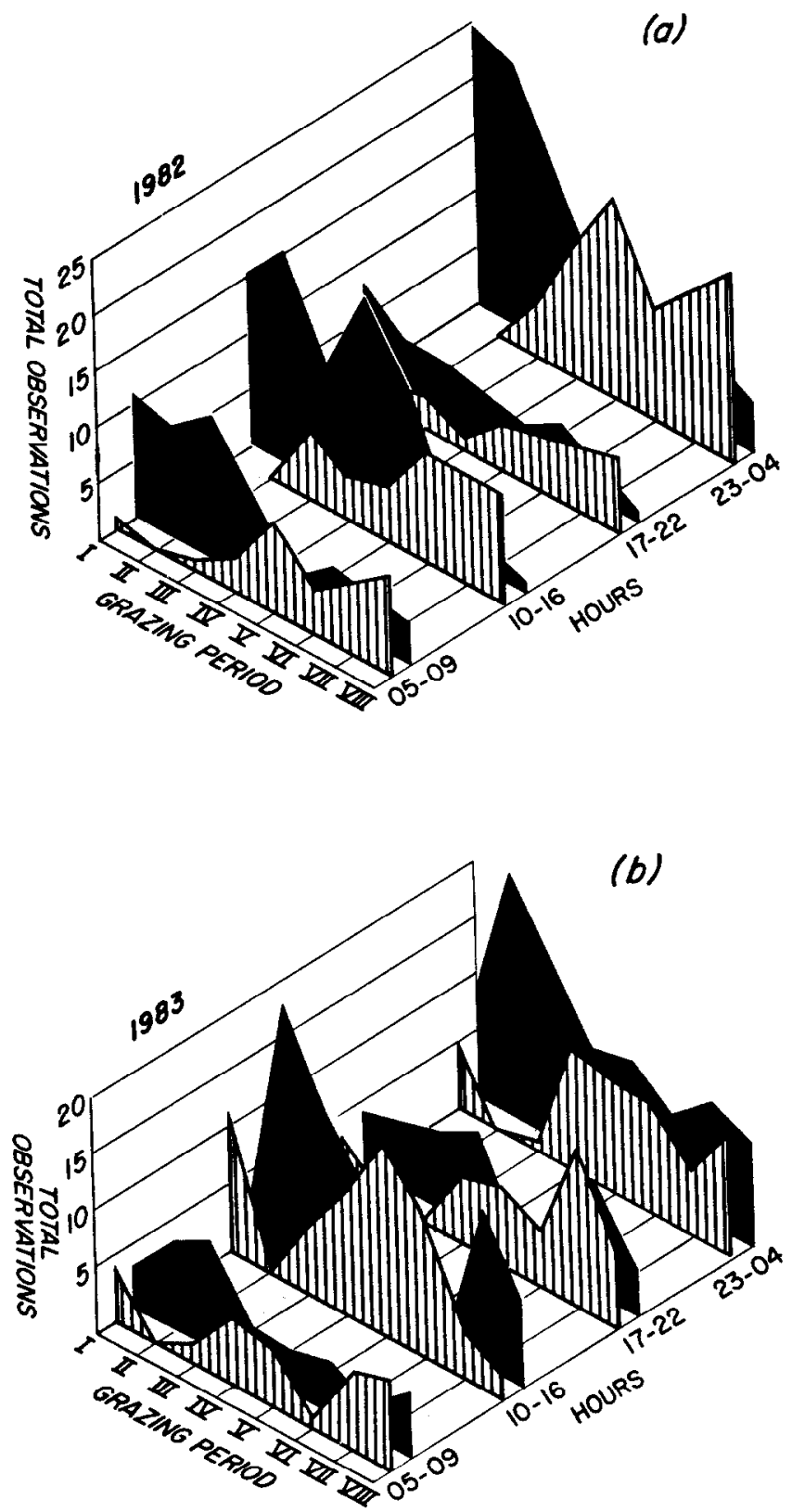

Fig. 6. Comparison of resting patterns by activity period in 1982 and 1983. Solid figures represent upland use; lined figures riparian use. Roman numeral $I=$ late June, $I I=$ early July, $I I I=$ late July, $I V=$ early August, $V=$ late August, VI = early September, VII= late September and VIII= early October.

August and early September when cattle rested more in the riparian zone during the heat of the day than in the uplands. The daytime resting accounted for $44 \%$ of the total observations during both periods. The lack of shade or very limited shade in these paddocks coupled with high daytime air temperatures may have limited insect pest activity and allowed cattle to remain where they had been feeding. Insect activity may also account for the late August resting level in the riparian zone during darkness (34\%). It is important to note that this level of nighttime use occurred during both years. Air temperatures from $2200-0500 \mathrm{~h}$ may be near optimum for insect pests which would cause cattle to seek relief in the uplands. The decline in riparian resting during the 10-16 h interval in late September and early October, 1983 was probably due to cooler daytime temperatures (Fig. 5) which caused cattle to avoid the shaded riparian zone. Cattle used riparian and upland areas to rest in about equally during the other hours of the day.

\section{Summary and Recommendation}

Cattle use of foothill upland and riparian zones for feeding and resting changes with forage and climatic conditions. If there was sufficient precipitation prior to the grazing season, cattle use was concentrated in the uplands until early July and then gradually shifted to the riparian zone. However, during a year of low precipitation, cattle used the riparian zone at higher levels during the early part of the grazing season. This pattern was probably a result of low upland forage quantity and quality.

Although cattle spent a significant amount of time resting and feeding in the uplands during late June and early July, feeding was the only significant use of riparian areas during September.

Although cattle did not spend a significant amount of time resting in riparian zones during late summer, they would rest more often in the riparian zone during hot August afternoons, but this only occurred if face flies were not a problem. Warm August nights may also have increased insect activity and reduced the amount of time cattle spent resting in the riparian zone during darkness. However, in September when air temperatures declined to near $0^{\circ} \mathrm{C}$ and wind speeds were $2.4 \mathrm{~ms}^{-1}$ for an extended period, cattle spent a significant amount of their resting time in the riparian zone.

Because cattle quickly adjust to daily variations in climatic conditions, rapidly fluctuating air temperatures and wind speeds can cause major shifts in activity patterns over a 24-h to 48-h period. Consequently, prediction of resting patterns will be tenuous except during periods of cold, windy weather. However, changes in forage production/quality occur more slowly and therefore appear to produce more predictable changes in cattle use patterns.

As upland forages mature and become less palatable, cattle will concentrate feeding activities in the riparian zone. Even though the riparian zone may make up a small proportion of the pasture's total available forage, it may supply the bulk of cattle forage consumption during late August and September. To reduce riparian impacts during this period, stocking rates should be based on the forage available in the riparian zone rather than an average for the entire pasture or allotment. During drought periods it may be necessary to make such stocking rate adjustments early in the grazing season.

\section{Literature Cited}

Branson, F.A., G.F. Gifford, and J.R. Owen. 1972. Rangeland Hydrology. Soc. for Range Manage. Range Sci. Ser. No. 1. Denver, Colo.

Bryant, L.D. 1982. Response of livestock to riparian zone exclusion. J. Range Manage. 35:780-785.

Davis, J.W. 1982. Livestock vs. riparian habitat management-there are solutions. p. 175-186. In: Peek, J.M., and P.D. Dalke (eds.) 1982. Wildlife-Livestock Relationships Symposium. Proc. 10. Univ. of Idaho Forest. Wildl. and Range Exp. Sta. Moscow.

Gomez, K.A., and A.A. Gomez. 1984. Statistical procedures for agricultural research. 2nd Ed. John Wiley and Sons, Inc. New York, N.Y.

Hull, J.L., G.P. Lofgreen, and J.H. Meyer. 1960. Continuous versus intermittent observations in behavior studies with grazing cattle. J. Anim. Sci. 19:1204-1207.

Kauffman, J.B., W.C. Krueger, and M. Vavra. 1983. Effects of late season cattle grazing on riparian plant communities. J. Range Manage. 36:685-689.

Kilgour, R., and D.C. Dalton. 1984. Livestock behavior. a practical guide. Westview Press. Boulder, Colo.

Marcuson, P.E. 1977. The effect of cattle grazing on brown trout in Rock Creek, Montana. Mt. Dept. Fish, Wild. and Parks. Fish. Div. Spec. Rep. Proj. No. F-20-R-21, IIa.

Myers, L.H. 1981. Grazing management vs. riparian management in southwestern Montana. Abstract Society for Range Management 34th Annual Meeting. Tulsa, Okla.

Nelson, A.B., and R.D. Furr. 1966. Interval of observation of grazing habits of range beef cows. J. Range Manage. 19:26-29. 
Platts, W.S. 1982. Sheep and cattle grazing strategies on riparian-stream environments. p. 251-270. In: Peek. J.M. and P.D. Dalke (eds.) 1982. Wildlife-Livestock Relationships Symposium Proc. 10. Univ. of Idaho Forest. Wildl. and Range Exp. Sta. Moscow.

Roath, L.R., and W.C. Krueger. 1982a. Cattle grazing influence on a mountain riparian zone. J. Range Manage. 35:100-103.

Roath, L.R., and W.C. Krueger. 1982b. Cattle grazing and behavior on a forested range. J. Range Manage. 35:332-338.
Severson, K.E., and C.E. Boldt. 1978. Cattle, wildlife and riparian habitats of the western Dakotas. p. 90-113. In: Management and Use of Northern Plains Rangeland. Reg. Rangeland Symposium. Bismarck, N.Dak.

Squires, V. 1981. Livestock management in the arid zone. Inkata Press Proprietary Limited. Melbourne Austr.

Western Division American Fisheries Society. 1980. Management and protection of western riparian stream ecosystems. A position paper. Tualatin, Ore. 